Pieter

Labuschagne

Prof Pieter Labuschagne,

Department of Political

Sciences, University of

South Africa, PO Box 392,

Pretoria 0003, Email:

labuspah@unisa.ac.za

DOI: http://dx.doi.

org/10.18820/24150479/

aa48i2.5

ISSN: ISSN 0587-2405

e-ISSN: 2415-0479

Acta Academica - 2016 48(2):

108-126

(c) UV/UFS

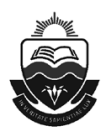

\section{South Africa After 20 Years Of Democracy: A Case Study}

First submission: 18 June 2016

Accepted: 21 September 2016

The two decades spanning the end of the $20^{\text {th }}$ and the start of the $21^{\text {st }}$ Century were important phases in the global process of democratisation. The 1990s were epitomised by the ground-breaking 1991 publication of Samuel Huntington's The Third Wave: Democratization in the Late Twentieth Century. Huntington's book crowned the global success of democracy, with a growing number of states adopting the principles of democracy. It seems that the next decade from 2000 to 2010 would be the continuation of the democratic trend with authoritarian regimes and their leaders toppling before the "next wave of democratisation". This notion was strengthened by a significant number of countries, including Turkey, Egypt, Libya and Ukraine, disposing of their leaders and adopting democratic principles. However, it seems that the transition from an authoritarian to democratic rule was more challenging, with the new democracies progressively showing distinct signs of vulnerability in sustaining democracy. The challenges to new democracies seemed to coincide with a wider, more comprehensive disillusion with democracy in general. The scepticism towards democracy increased at a juncture when authoritarian rule seemed to pose a real challenge to democracies, with the rise of China on the global stage. The article is concluded with an investigation into the state of democracy in South Africa in the form of a case study. The reference in the article to other countries is for explanatory purposes only. 
I a lecture to commemorate the signing of the Magna Carta, Tom Bingham (2010: 172) emphasised the importance of the rule of law, its interrelationship with democracy and good governance. He explained that the rule of law encompasses and embodies multiple ideas, values and ideals that are essential for a sustainable and deeply penetrating democracy. According to Bingham (2010: 172) the primary principle embodied in the rule of law is a limitation on state power and authority. In addition authority should be expressed through publicly disclosed laws, duly promulgated by the elected representatives of the people. The laws should then be enforced by an independent judiciary in accordance with established and accepted procedures. This dictum emphasises the value of the rule of law, its relationship with democracy and its importance in modern society to ensure good governance.

The Universal Declaration of Human Rights, later international instruments and the European Court of Justice have all referred to the rule of law as their guiding principle. The European Commission has consistently linked democratisation with the rule of law, a respect for human rights and good governance (Bingham 2010: 66-67 and Commission Communication to the Council and Parliament 12 March 1998 COM 98, par 34). The World Justice Project (WJP) and Freedom House agencies have consistently over decades provided empirical evidence to demonstrate the critical importance of the rule of law as the overarching umbrella for good governance and the protection of basic human rights. In annual reports they have demonstrated that the presence of the rule of law is essential for an emerging and newly founded democracy to complement a successful transition from authoritarian rule.

The emphasis on the rule of law and its importance for good governance must be seen against the background of recent growing concern among scholars regarding the sustainability of democracy during the post-transition phase from dictatorship or authoritarian rule. The earlier optimism that followed the third global wave of democratisation (Huntington 1991) has been tempered by a discernible global slide-back or democratic recession during the early part of the $21^{\text {st }}$ Century. The setback and/or collapse of new democracies shortly after the optimism of the Arab Spring have casted doubt on democracy's sustainability in post-transition, post-authoritarian regimes (Diamond 1999, Fukuyama 1991 and Plattner 2016).

In the light of the renewed scepticism about the status of democracy my aim is to revisit its basic principles, specifically the important link between the rule of law, democracy and good governance (Fukuyama (1991), Plattner (2016) and Diamond (2015). I will argue that the inability to deepen democracy, which invariably leads to a defective democracy, is the inability to establish a link between the rule of law and good governance. 
Merkel (2004: 33-58) has constructed a theoretical, analytical model in which he classifies the characteristics of failed democracies, which also contain the underpinning reasons for the inability of "new" democracies to sustain a democracy. The aim of the article is to combine Merkel's theoretical typology of defective democracies with the empirical values provided by grading agencies regarding the rule of law, democracy and good governance (Bingham 2010: 66-67). The WJP and Freedom House scores on the rule of law index will then, in a concluding step, be utilised to quantify and investigate the status of democracy in South Africa.

\section{Democracy: some introductory remarks}

The shortcomings of a democracy can hardly be obscured because the openness of democracy is the hallmark of the system. Former United Kingdom prime minister Winston Churchill famously noted in 1947 to the UK House of Commons that "democracy is the worst form of government except all the other forms that we have tried from time to time" (Heywood 2004: 66).

Huntington (1991) has encapsulated the global successes of democracy in his paradigm-shifting work, The Third Wave: Democratization in the late twentieth century. Huntington outlined the upsurge of democracy in three distinct waves, with the third wave in the 1990s, that have substantially increased the number of transitions from dictatorship and authoritarian rule to democracy. He also pointed out that the successes of newly democratised countries by far outstripped the perceived democratic breakdowns.

The Arab Spring early in the $20^{\text {th }}$ Century, when several authoritarian regimes were ousted, raised expectations of a 'fourth democratisation wave'. The Arab Spring seemed to strengthen the global notion of the desirability and supremacy of democracy. However, this early optimism was soon tempered by the general instability of the 'new' democratic systems in Egypt, Ukraine, Iraq and Libya after the overthrow of their autocratic rulers (The Economist 2014: 64). The general view from observers was that many of the new democracies were too weak to be maintained and that their initial adoption of democracy was 'pluralism by default', rather than a true transition (Plattner 2016: 3).

South Africa's democratisation and transition from authoritarian rule to an inclusive constitutional democracy were globally hailed as a miracle. Two decades later the evaluation of South Africa's democracy is that acceptable levels of political stability have been maintained and that the regular elections are indicative of the process of democratic consolidation. However, on closer inspection it seems if small cracks have started to appear in the democratic 
façade and the sustainability of democracy in the country. The ruling African National Congress's (ANC's) 20-year political dominance has effectively institutionalised a de facto one-party state and its rule has been progressively associated with high levels of corruption, breakdown of security and self-serving members that threaten a still vulnerable democracy (Mail \& Guardian 2014: 10).

\section{Is democracy on the decline?}

The critical question in the light of the 'democratic recession' is whether democracy has globally reached its zenith and if it is actually on the decline. Plattner (2016:2) analysed the validity of the question and argues, with reference to Huntington's The Third Wave: Democratization in the late twentieth century, that the viability of global democracy should be analysed within a historical and global context. He emphasises that the statistical evidence is still in favour of democracy, with $63 \%$ of all states classifiable as electoral democracies and $46 \%$ as substantial democracies (Plattner 2016: 1).

However, despite positive figures the outlook for the expansion of democracy is dampened by persistent evidence that the global wave of democratisation has indeed slowed after its initial successes at the end of the $20^{\text {th }}$ Century and early $21^{15 t}$ Century. This seems to confirm the emerging notion that "new" democracies are especially vulnerable in their initial quest to deepen and consolidate their democracies. Diamond (2015: 5) agrees that a period of global democratic recession has followed the Arab Spring, with Freedom House indicators suggesting that most of the recently democratised countries are experiencing a discernible trace of a mild democratic slide away. The reasons for the democratic recession are complex, but in Libya, for example, the role of the military as a second source of power is an obstruction to democracy (Alfasi 2016: 16).

In a counterargument, Levitsky and Way (2015: 115) provide evidence from other agencies, such as Polity IV and the Economist Intelligence Unit, that dispute the notion of a democratic recession and stress that the change in overall scores of democracy is minimal. They argue that the "democratic recession" is a case of pseudo-democracies, as in Egypt, Ukraine, Iraq and Libya, that were built on the notion of "pluralism by default" rather than true democracies.

\section{The disillusion with democracy}

The failure of democracy in a number of countries following the Arab Spring had a psychological impact on the general confidence in democracy and sparked a level of disillusionment regarding its sustainability. A Freedom House survey indicated that 2013 was the eighth consecutive year in which global freedom was on the 
decline. The upswing of democratisation between 1980 and 2000, with limited setbacks, seems to have been followed by a gradual downward trend. The renewed faith in democracy that flared up during the Arab Spring, with the overthrow of unpopular regimes and authoritarian rule, was therefore rather short-lived, as proved by the failure of democracy in Egypt, Ukraine and Libya (The Economist 2014: 64; Alfasi 2016: 15-16). The reasons for the decline or setback of democracy are complex and will be outlined below.

Bad governance: Diamond (1999) and Fukuyama (1991) maintain that the main reason for the perceived downturn or slowdown of democratisation is "bad governance". The reason for the failure is that leaders of the new democracies failed to build well-functioning and effective states (Plattner 2016: 4). The ineffective democracies then lead to stagnation or negative economic growth, poor public service, lack of personal security and systemic corruption. Fukuyama (1991: 115) contends that the "legitimacy of many countries around the world depends less on the deepening of their democratic institutions than on the ability to provide high quality governance", which is then unfairly blamed on democracy.

Financial crisis of 2007-08: The global financial crisis towards the end of the first decade of the $21^{\text {st }}$ Century had a negative psychological and financial impact on the legitimacy of democracy. The financial crisis following the global economic bubble revealed the Western powers' fundamental weakness of extending too much individual freedom to its citizens. Governments allowed dangerous levels of individual debt to develop, because politicians believed that they could control boom-bust cycles and tame financial risks. When the financial bubble burst they then bailed out bankers with taxpayers' money and the middle class had to absorb the financial burden (The Economist 2014: 64).

The perceived success of authoritarian regimes: The financial success of the Chinese Communist Party's authoritarian rule early in the 21 $1^{\text {st }}$ Century broke the democratic world's monopoly on economic progress (The Economist 2014: 64). China has astonished industrialised nations with an economic growth rate during the last two decades that has outstripped most of its rivals. Plattner (2016: 4) describes China's advances in economic growth as a sign of national self-confidence that has coincided with economic prowess from a number of authoritarian countries led by the so-called big five: China, Russia, Iran, Venezuela' and Saudi Arabia.

The authoritarian rulers of China, Russia, Iran, Saudi Arabia and Venezuela are also "united" in their desire to prevent any infringement on their sovereignty in

1 The vulnerability of states built on one commodity (oil) has been proved with the dramatic economic collapse of Venezuela, reducing the big five to the big four. 
the name of democracy and human rights. They work together on international forums, learning from one another and sometimes even copying measures from their counterparts. China's laws restricting the funding of civil society and the way it controls internet and discussion forums have been copied by fellow authoritarian states (Plattner 2016: 4).

China seems to be able to successfully distribute its economic advances to improve the living standard of its general population. In a study conducted by Harvard University it was noted that when the USA's economic growth peaked, it was able to double the living standards of its citizens every 30 years. China has surpassed this achievement and has managed to double living standards every 10 years for the last 30 years. The current financial downturn in the USA is partly the result of striving for too much economic freedom through abolishing security banking measures. The economic downturn has affected the middle class in the USA, which has been experiencing a continued drop in living standards for more than a decade, while the government is facing a national debt of 19 trillion dollars (Sparks 2016).

China was able to tackle the social problems of state building that democracies have been struggling with for decades in a relatively short period. The government has extended pension coverage to 240 million rural dwellers, far more than the total number covered by America's public pension system. It seems that many ordinary Chinese are prepared to put up with their closed system if it delivers economic growth. The 2013 Pew Global Attitudes survey showed that $85 \%$ of Chinese were happy with their country's direction compared to $31 \%$ of Americans (The Economist 2014: 64).

China has been criticised for suppressing political freedom and for its strict control of public opinion by imprisoning dissidents and controlling and censoring internet discussions. However, the irony is that the regime paradoxically is paying close attention to public opinion through its monitoring of opposition views.

In oil-rich Saudi Arabia the royal family has kept a tight leash on political freedom. Saudi Arabia's strict authoritarian state, ruled by a monarchy, has kept a lid on all political reform, but the income from oil has allowed the rulers to maintain a high economic growth rate. Saudi Arabia's gross domestic product (GDP) has averaged 4,91\% from as far back as 1969 and its GDP for the fourth quarter of 2015 reached a high of 3,60\%. Saudi Arabia's per capita GDP is among the highest in the world and currently stands at US \$17 819 (www.trandingeconomics.com. saudi/gdp). However, political freedom remains a contentious point and in this regard the regime has a relatively average score. The World Bank rates countries' political stability on a scale of 2,50 (strong) to -2,50 (weak) and Saudi Arabia has scored only an average -0,3 over the period 1996-2014 (www. theglobaleconomy. com.saudi/stab). 
The slow process of democracy building: The problem facing new democracies is the protracted period necessary to build democratic institutions and to put efficient processes in place to sustain a democracy. It is a challenge to build a democratic culture in a historically non-democratic country. This dispels the notion that democracy will grow rapidly as soon as the seeds have been planted. Turkey, which initially seemed to be able to combine moderate Islam with prosperity and democracy, seems to be descending into disconcerting levels of corruption and autocracy (Altundal 2016: 14). In other "new" democracies (Bangladesh, Thailand and Cambodia) the challenges have also slowed democratic consolidation with opposition parties who have boycotted recent elections or refused to accept their results (The Economist 2014: 64).

\section{The democratic distemper}

The threat to democracy seems to come from all directions - from above, from below and from within. The conventional notion that democracy should exclusively be expressed through the nation state is under threat from above and from below. The growing globalisation and surrendering of power to organisations and supranational organisations, such as the International Monetary Fund and the European Union, pose a threat to national governments from above. National politicians have to respond to growing globalisation by limiting their discretion and handing power over to unelected technocrats sitting in organisations such as the European Union. From below democracy is threatened by micropowers (non-governmental organisations and lobbyists) and breakaway nationalists such as the Scots in the United Kingdom and the Catalans in Spain (The Economist 2014: 64).

However, the biggest single threat to democracy comes from within the system itself and originates from the constituents who are progressively expressing their dissatisfaction with and cynicism about democracy. Ordinary citizens have globally demonstrated their lack of interest in the democratic process with a steady decline in party membership and also with a low voter turnout at elections. The available evidence shows that party membership is declining all over the developed world. In the United Kingdom the number of people who are members of a political party has dropped from 20\% in 1950 to $1 \%$ in 2015. In tandem with declining party membership the voter turnout is also falling; a study of 49 democracies found that turnout declined by 10 percentage points between 1980-84 and 2007-13. A survey of seven European countries found that half of the voters "had no trust in government". A YouGov opinion poll in 2012 of British voters found that $62 \%$ of those polled agreed that 'politicians tell lies all the time' (The Economist 2014: 64). 
The earlier euphoria in South Africa, when the country was democratised after decades of white authoritarian rule, is starting to show distinct signs of disillusionment with democracy. The percentage of registered voters for the 2014 general election already declined. However, it is the voter turnout, against the proportion of eligible voting age population, which is the most telling. The voter turnout at the 1994 election was $84 \%$ and during the consecutive elections this figure gradually dropped to $72 \%$ in 1999 and to $58 \%$ in 2004. There was a slight rise during the 2009 election when the turnout recovered to $60 \%$, but it dropped away again to 57\% in 2014 (Institute for Security Studies, Policy Brief 61: August 2014).

Voter turnout is of extreme importance because it is predominantly an indicator of the health of politics in a polity and in particular in a democracy. Voter participation can provide a good indication of the prevailing feeling in a society, especially the level of legitimacy that the political system enjoys as well as the level of activity among their members. In this regard the viewpoint that voters really want to participate and interact with the polity is important (Botha 1994: 42).

The ruling ANC is also feeling the effect of the disillusion regarding the performance of government among its supporters. Many ANC supporters and members make a distinction between the party and the state and remain loyal to the party while opposing the government with service delivery protests. Despite this phenomenon ANC president Jacob Zuma, on the eve of the 2016 local elections, expressed his concern with the drastic drop in ANC membership from a high of 1,2 million members to 789 000. It represents a drop of 37\% in members between 2012 and 2015. In six of the nine provinces ANC membership has dropped and for the first time in the history of the party its hold on power is really challenged with dwindling ANC support in three of the nine mega-metro councils.

www.ssinesstech.co.za.news/government/100848/massive-drop-in-ancmembership

\section{Defective democracies - the transitional challenge to a functional democracy}

The perceived inability of democracies, especially in the European Union, to deal with the migration from mainland Africa to Europe has become a breeding ground for populist parties opposing the current migrant policies and liberal democratic systems. More conservative populist parties, such as Geert Wilders' Party for Freedom in the Netherlands, Marine Le Pen's National Front in France and right- 
wing movements in Germany, have gained ground against the democratically elected leaders in their countries (The Economist 2014: 64).

The rise of right-wing parties highlights the importance of strong decisive leadership, which seemed to be lacking among democracies in Europe. As indicated earlier, Diamond (1991) and Fukuyama (1991) have both attributed the slowdown or erosion of democracy to "bad governance" or a lack of effective leadership, which leads to lagging economic growth, poor public services, lack of personal security and pervasive corruption. The citizens who had rising expectations within a "newly" democratised system feel disappointed and even betrayed by the promise of democracy. The notion is also prevalent in nondemocratic countries, but in "failed" democracies constituents have voted for government and the perception is that democracy can't deliver on its promises. Fukuyama (1991) emphasised that "new" democracies should pay greater attention to strengthening democracy and to state building by adopting good policy implementation and by simply administering good governance. However, these ideals could be an elusive goal in the recently democratised countries given the inexperience of the leaders and a lack of historical exposure to a democratic culture (Plattner 2016: 4).

Merkel (2004: 33) provided a typology of 'embedded and defective democracies' which is a useful framework for identifying and classifying inherent defects in a democracy. He explains that an embedded liberal democracy consists of four partial regimes (properties): a democratic electoral regime, effective power to govern, political rights of participation/civil rights and horizontal development. Merkel's four partial regimes/properties (see below) can be categorised and aligned with the various permutations of democracy.

Merkel's typology of embedded and defective democracies

i. Exclusive democracy (a democratic electoral regime). An embedded defective democracy excludes sections or individuals of the population from political participation in the country.

ii. Tutelary democracy (effective power to govern). An inability of government to govern and the elective representatives fail to exercise the authority to rule.

iii. Illiberal democracy (political rights of participation/civil rights). Civil and political rights of citizens are not guaranteed within a system that is based on the rule of law.

iv. The absence of a delegative democracy (horizontal development). The internal checks and balances between the different state institutions 
(legislative, executive and judiciary) are not functioning properly or are not based on an effective system of the rule of law. The rulers are not being held accountable by the constituents and the other state institutions.

\section{South Africa: a case study}

The aim of the article is to conduct an investigation into the state of South Africa's democracy. In the investigation special attention will be placed on how democracy has been sustained since 1994 and the level of legitimacy it has maintained. ${ }^{2}$ The investigation will be conducted on the basis of Merkel's (2004: 33) fourfold typology of defective democracies as outlined in the previous subsection. The typology will serve as a structural framework to analyse South Africa's progress and sustainability of its democracy. In order to quantify the progress and sustainability the scores and global ranking of the WJP's Rule of Law Index and Freedom House will be utilised.

The WJP's Rule of Law Index provides a useful index to quantify a country's rule of law status. The rule of law index is divided into eight sub-factors: constraints on governmental power, the absence of corruption, the presence of an open government, the presence of fundamental rights, the maintenance of order and security, regulatory enforcement, the practicing of civil justice and criminal justice. The aim is to indicate South Africa's scores in each sub-factor and its global ranking.

The first step, before quantifying the scores, is to outline the status of South Africa's democracy against Merkel's typology.

\section{(i) Exclusive or democratic electoral regime}

On the surface South Africa's democracy display high levels of legitimacy with regular general and local elections in which all registered parties participate. The proportional system allows smaller parties with limited support to be elected to parliament and to participate at all levels of government, which dispels the danger of an exclusive regime in South Africa.

However, on the flip side the rise in service delivery protest in the country (which will be dealt with in the next subsection on tutelary democracy) has highlighted a perceived shortcoming that degrades the inclusivity of the democratic regime. On the local level municipal managers are predominantly political appointees,

2 See Kotze DJ (2004) The nature of democracy in South Africa. Politeia, Vol 23, No 3, for an analysis of the South African democracy covering the period 1994-2004. 
appointed on the basis of their seniority in the ruling party. Their lack of legitimacy within the local community and their lack of managerial experience, have led to a failure to provide and maintain efficient standards, resulting in service delivery protests (Nleya 2011: 5).

The general perception is that municipal managers have little obligation to their constituents, because their loyalty is directed to party structures and the party bosses who appointed them. The rise in the number of service delivery protests nationwide therefore relates directly to the political appointees' inefficiencies and their lack of accountability to the voters in their wards (Nleya 2011: 5).

The Institute of Security Studies (ISS) policy briefs link service delivery protests directly to the people's frustration and dissatisfaction with their exclusion, their inability to hold municipal managers accountable and their lack of input in the appointment of managers. The communities argue that this lack of transparency and accountability is contrary to the Local Government Municipal Systems Act 32 of 2000 (Managa 2012: 4, ISS policy brief).

\section{(ii) Tutelary democracy}

Merkel emphasised the importance of the principle that the power (authority) to govern should be in the hands of the elected representatives. If an external group such as the military makes the decisions, they in effect "veto" the elected representatives' power, circumvent the salient features of a representative democracy and create a tutelary democracy. This amounts to external "state capture", which constrains the effective-to-govern attribute of a democracy. Altundal (2016: 10-15) pointed out how Libya's democratisation was frustrated by the role of the military as a "second" source of power in the country. It should be recognised that state capture or external unduly influence could also be subtle and clandestine, frustrating the will of elected representatives by stealth. ${ }^{3}$

The problematic aspect is that state capture severs the direct relationship between a government and its constituents; as it is an external source of power it cannot be held accountable within the system. The state also pays more for goods and services that could have been conducted through formal channels and in the

3 The accusations of state capture in South Africa are rife with evidence that shows that the Gupta family was able to exercise undue influence on government. The family was even able to offer ministers and other senior positions a privilege linked to the executive power. The Deputy Finance Minister, Jonas Mcebisi, has revealed that members of the Gupta family, who apparently enjoy close ties with President Jacob Zuma, approached him with an offer to be the next Minister of Finance. A similar accusation was made by a senior member of parliament, Vytjie Mentor, who was also offered a senior position. 
process encourages corruption. State capture also undermines the effectiveness of the state, because functions are re-directed away from the state's formal apparatus to patronage service providers. The integrity and functionality of the state is compromised because "services by stealth" short-circuit the internal public checks and balances, putting them beyond the scrutiny of the auditorgeneral, the public protector and the media. ${ }^{4}$ (Fin 24: www.fin.24.com/opinion/ mcebisi-jonas-opens-up-on-state-capture-20160422).

The creation of a pseudo "government", parallel to constitutionally created state institutional structures, undermines the efficiency of the state morally and functionally (Fin 24: www.fin.24.com/opinion/mcebisi-jonas-opens-up-onstate-capture-20160422). The success of a democracy depends on the ability of government to govern effectively and to deliver basic services. Plattner (2016:4) explains that the "disappointment with democracy's failure to deliver goods and services to its citizens accounts partly to its vulnerability to breakdown in countries that have adopted it for the first time" (Diamond 1991, Fukuyama 1991).

In South Africa poor service delivery has manifested in nationwide service delivery protests, rising from 107 in 2009 to 173 in 2012 and reaching a high of 191 in 2014 (Eybers \& Mapumolo 2016: 15). During the four months between 1 January and 30 April 2016 a high of 82 service delivery protests have been reported, which amounts to a service protest almost every second day. Service delivery protests normally level off or decline in the run-up to a local election because of the higher level of political engagement. In the corresponding period before the 2011 local elections there were only 70 service delivery protests leading up to the election (Heese 2016: 1, Rapport 12 June 2016). Many analysts are of the opinion that the number of service delivery protests during the 2016 local election year is set to reach an all-time high (Steyn, 2016: 1).

\section{(iii) Liberal democracy}

Merkel's (2004: 33) third property of a defective democracy is an illiberal democracy with an absence of guaranteed civil and political rights. In a liberal democracy civil and political rights do not only exist de jure, but also de facto

4 The Sunday Times (2016) revealed in a leading article that the government had concluded a deal of 60-70 billion US dollars with Russia for the installation of nuclear power plants, an amount equal to South Africa's total annual tax revenue, which put the treasury under severe pressure with the possibility that the repayment of loans may be defaulted. The transaction was allegedly the result of a close relationship between Zuma and his Russian counterpart, Vladimir Putin. The deal is another example of an allegiance not to the electorate or in public interest, but to politically connected interests. The previous Minster of Finance, Nhanhla Nene, who was sceptical about the transaction, was released from his position shortly after the deal was concluded. 
(Altundal 2016: 10). Civil and political rights in South Africa are constitutionally protected and compare favourably with other "new" democracies. However, the scores are still lagging behind the benchmark in developed democracies such as the United Kingdom. Despite South Africa's satisfactory scores Freedom House rating's shows that the government's planned curbing of the media had a negative influence on the score for the freedom of the press; it dropped from an earlier favourable score of 100 to 79.

The freedom to protest and to exercise political rights is an important part of a liberal democracy. In South Africa protestors' political rights have progressively been infringed during the last few decades, which have dented the country's status as a liberal democracy. The 2012 Marikana massacre left 34 striking mine workers dead in clashes with police and in the same year 38 ANC members and 13 civilians were killed in what were termed as political killings (www.corruptionwatch.org.za).

\section{(iv) Delegative democracy}

Legal historian WA Robson wrote in the well-known publication Justice and Administrative Law that the threefold division between a legislator, an administrative official and an independent judge is a necessary condition for the rule of law in a modern society and therefore for government itself (Wade \& Bell 1993: 50) This constitutional arrangement should be supported by functional internal checks and balances, operating between the different state organs (legislative, executive and judiciary) and by an imbedded culture of institutional and public accountability.

The separation of powers or trias politica doctrine was propounded by John Locke, but is usually associated with the teachings of Montesquieu. The separation of powers entails that the freedom of the citizens can only be ensured if the abuse of power in a state is prevented by dividing the government's authority into legislative, executive and judicial branches with effective cross-institutional checks and balances. The separate functions entails that the legislative authority make the rules of law, the executive authority execute and enforce the rules of law and the judicial authority adjudicate transgressions of the rules (Rautenbach \& Malherbe 1998: 96). In a centralised democracy the executive controls both the legislature and the judiciary which substantially degrades the effectiveness of checks and balances between the state institutions.

Klüg (2002: 67) emphasises the importance of the presence of the rule of law and the symmetrical and congruent relationship between the decision makers and the recipients of the decisions. A fully functional democracy consists of a representative and limited government, based on the separation of powers, and 
an independent judiciary. It is of critical importance that the judiciary, as watchdog and "protector" of the constitution, is independent from institutional control (Rautenbach \& Malherbe 1998: 96).

South Africa's Westminster style parliamentary system unfortunately frustrates the separation of powers principle. As a result of the fusion of the legislative and executive branches, the system can be best described as a partial separation of powers. The fusion between the executive and the legislature puts an added responsibility on the judiciary to act as arbiter and watchdog to ensure accountability and to constitutionally enforce the system of checks and balances (art 165).

The current lack of accountability and/or respect by the executive for the judiciary has the potential to erode the status of the rule of law in South Africa. The Constitutional Court on 31 March 2016 ruled on the Nkandla case and found that the Public Protector's report was binding on the president. Chief Judge Mogoeng and 10 constitutional judges ruled that the National Assembly had flouted the constitution and also failed in their constitutional duty to hold the president accountable. The Court also found that Zuma failed to uphold, defend and respect the constitution. The finding exposed the general disrespect of the executive and the legislature for the constitution (https//www.enca.com). ${ }^{5}$

President Zuma was unfazed in his response and told the House of Traditional Leaders on 4 April 2016 "not to trust the judges" because the law always went to the other side and that the judges convicted you even if you told the truth (The Citizen 8 April 2016). The National Prosecution Authority's (NPA) legitimacy has also been severely tarnished with a series of incidents undermining its creditability. The downwards spiral culminated with the request of the General Council of the Bar in 2016 that two senior members of the NPA, Nomgcobo Jiba (national deputy director) and Lawrence Mrwebi (head special investigative unit) be scrapped from the roll as advocates. The request of the General Council of the

5 In South Africa concern is expressed about the executive's stance and lack of respect for the rulings of the judiciary. In an unprecedented step Heads of the Courts and senior judges have requested Chief Justice Mogoeng to meet with the president regarding the unfounded criticism by senior members of the ruling party on the judiciary. The senior members of the judiciary raised concern about the repeated attacks on the judiciary, which undermines the rule of law. The request of the Chief Justice to meet with the President follows on the executive's continued refusal to act on judicial rulings. The concern was especially aimed at the ruling of the Gauteng High Court in South African Litigation Centre vs Minister of Justice and Constitutional Development and Others (2015) JOL 33405 (GP). An arrest warrant was issued for the Sudanese premier, Omar al-Bashir, wanted by the International Criminal Court. The government chose to ignore the ruling of the High Court and the subsequent request by the ICC which they are a signatory of (www.dailymaverick. co.za/article/2015-06-05). 
Bar was based on ethical grounds and the damage that the members have caused to the image of the law profession. The impact of the request had a devastating impact on the NPA's efficiency, creditability and general morale. The adverse reaction of the NPA to the request was not to decisively root out the cancer in the soul of the unit, but rather to thank the two members for their services and to put them on special leave (Kriegler, 2016: 19).

\section{The alignment of Merkel's four properties with the World Justice quantitative report}

The aim of this subsection is to align Merkel's fourfold typology of a defective democracy with scores and ratings from the World Justice report. This is done in categories based on the eight sub-factors of the rule of law Index. South Africa's scores are provided in these categories followed by its global ranking.

WORLD JUSTICE REPORT: SOUTH AFRICA'S SCORE

SCORE: 1 (high), 0 (low) / WORLD RANKINGS

\begin{tabular}{|c|c|c|c|c|c|c|c|}
\hline $\begin{array}{c}\text { Constrain } \\
\text { Government's } \\
\text { power }\end{array}$ & $\begin{array}{c}\text { Absence of } \\
\text { corruption }\end{array}$ & $\begin{array}{c}\text { Open } \\
\text { government }\end{array}$ & $\begin{array}{c}\text { Fundamental } \\
\text { rights }\end{array}$ & $\begin{array}{c}\text { Order \& } \\
\text { security }\end{array}$ & $\begin{array}{c}\text { Regulatory } \\
\text { enforcement }\end{array}$ & $\begin{array}{c}\text { Civil } \\
\text { justice }\end{array}$ & $\begin{array}{c}\text { Criminal } \\
\text { justice }\end{array}$ \\
\hline 0.61 & 0.52 & 0.62 & 0.63 & 0.62 & 0.5 & 0.56 & 0.56 \\
$40^{\text {th }}$ & $42^{\text {nd }}$ & $27^{\text {th }}$ & $39^{\text {th }}$ & $81^{\text {st }}$ & $33^{\text {th }}$ & $39^{\text {th }}$ & $39^{\text {th }}$ \\
\hline
\end{tabular}

Below Merkel's four properties of defective democracies are aligned with the eight rule of law properties of the World Justice Report.

\begin{tabular}{|l|l|}
\hline \multicolumn{1}{|c|}{ MERKEL's FOUR PROPERTIES } & $\begin{array}{l}\text { RULE OF LAW AND THE EIGHT FACTORS FROM THE } \\
\text { WORLD JUSTICE REPORT }\end{array}$ \\
\hline $\begin{array}{l}\text { Exclusive democracy: } \\
\text { No citizens or groups should be excluded from } \\
\text { political participation in a democracy. }\end{array}$ & Open government \\
\hline $\begin{array}{l}\text { Tutelary democracy: } \\
\text { There should be effective power to govern, } \\
\text { which should ideally be situated in the elective } \\
\text { representatives in a country. }\end{array}$ & Absence of corruption; order and security \\
\hline $\begin{array}{l}\text { Liberal democracy: } \\
\text { It is important that the civil and political rights of } \\
\text { citizens are guaranteed within a system based } \\
\text { on the rule of law. }\end{array}$ & Fundamental rights \\
\hline
\end{tabular}




\begin{tabular}{|l|l|}
\hline \multicolumn{1}{|c|}{ MERKEL's FOUR PROPERTIES } & $\begin{array}{c}\text { RULE OF LAW AND THE EIGHT FACTORS FROM THE } \\
\text { WORLD JUSTICE REPORT }\end{array}$ \\
\hline $\begin{array}{l}\text { Delegative democracy: } \\
\begin{array}{l}\text { The internal checks and balances between the } \\
\text { different state organs (legislative, executive and } \\
\text { judiciary) should function properly and the rule } \\
\text { of law should apply. The rulers should be held } \\
\text { accountable by the constituents and the other } \\
\text { organs of the state with no interference between } \\
\text { state institutions. }\end{array}\end{array}$ & $\begin{array}{l}\text { Constraints on governmental power, regulation } \\
\text { enforcement, criminal justice, civil justice. }\end{array}$ \\
\hline
\end{tabular}

In the diagram below South Africa is scored on the basis of the properties and factors (above).

The values are expressed as high (adherence) - medium - and low.

\begin{tabular}{|l|c|c|c|c|c|c|c|c|}
\hline Country & $\begin{array}{c}\text { Constrain } \\
\text { government }\end{array}$ & $\begin{array}{c}\text { Absence } \\
\text { corruption }\end{array}$ & $\begin{array}{c}\text { Open } \\
\text { government }\end{array}$ & Rights & $\begin{array}{c}\text { Order } \\
\text { Security }\end{array}$ & $\begin{array}{c}\text { Efficient } \\
\text { regulation }\end{array}$ & $\begin{array}{c}\text { Civil } \\
\text { justice }\end{array}$ & $\begin{array}{l}\text { Criminal } \\
\text { justice }\end{array}$ \\
\hline $\begin{array}{c}\text { South } \\
\text { Africa }\end{array}$ & Medium & Medium & High & Medium & Low & High & Medium & Medium \\
\hline
\end{tabular}

The rating for South Africa shows positive attributes and acceptable levels of governance. However, there are areas of concern, particularly in terms of order and security. The erosion in relation to internal checks and balances and the rising levels of corruption in the country are also areas of concern. It is evident that corruption poses the danger of becoming systematic and needs to be controlled.

\section{Conclusion}

The first inference from South Africa's scores and ratings is that the state of its democracy is stable, although there are some areas of concern. Internal security has deteriorated with a related impact on economic development, because this deters international investors. On the institutional level the politically motivated disrespect for the internal checks and balances and the unwillingness to exercise proper accountability poses a real threat to the democracy. The danger to the judiciary is also apparent and is reflected in the average scores with reference to civil and criminal justice.

South Africa's rule of law scores also seem to be on a gradual downward slide. In the 2011 Ibrahim Index of African Governance South Africa is ranked in fifth position in Africa regarding adherence to the rule of law, accountability and democratic participation. The fifth position is lower than the earlier higher grading 
and shows a downward trajectory from its 2005 second placing. Freedom House has also downgraded South Africa's status of the press from free to partly free (Freedomhouse.org/blog/south-african-democracy-rule-of-law-and-future).

It has been emphasised in the article that the challenge to deepen democracy and to progress towards democratic consolidation is located in the attributes of good governance. South Africa's government should commit itself more strongly to the rule of law, which includes the important democratic principle of accountability. The acid test for South Africa in the long term is to prove that democracy is indeed de facto sustainable, and that it is not descending in a slow downward trajectory. It is important that the democratisation of South Africa is successful to avoid not to be labelled as another example of pluralism by default.

\section{Bibliography}

ALFASI K (2016) Is democracy in decline? Democracy \& Society Vol 13(1): 15-16.

ALtUNDAL U (2016) Regime change within defective democracies: Turkey in the early 1990s and 2010s. Democracy and Society 13(1): 10-14.

BINGHAM T (2010) The rule of law. London: Penguin Books.

BотнA S (2004) Ten years of democracy: characteristics of and changes in South Africa's party system. Politeia 23(3): 25-35.

Collier D AND LEVITSKy S (1997) Democracy with adjectives: Conceptual innovation in comparative research. World Politics 49(3): 430-451. https:// doi.org/10.1353/wp.1997.0009

Commission Communication to the Council and Parliament 12 MARCH 1998 COM 98, PAR 34.

DIAMOND L (1999) Developing democracy: Toward democratic consolidation. Baltimore: John Hopkins University Press.

DiAmond L (2015) Facing up to the Democratic recession. Journal of Democracy 26(2): 141-155. https://doi.org/10.1353/jod.2015.0009

Eybers O AND MAPUMOLo Z (2016) New stats show that 9 of 11 protests a day is peaceful. The Mail and Guardian, 8 June 2016: 15.

FREEDOM HOUSE (2014) Freedom in the world: The annual survey of political rights and civil liberties. <Freedomhouse.org/blog/south-african-democracyrule-of-law-and-future?> (accessed 15 March 2016).

FukuYAma F (1991) Liberal democracy and the end of history. London: Penguin Books.

Heywood A (2004) Politics. London: MacMillan.

HUNTINGTON SP (1991) The third wave: Democratization in the late twentieth century. Norman: University of Oklahoma City Press. 
InStitute for SeCURity Studies, Policy Brief 61: August 2014.

KLÜG H (2000) Constituting democracy: Law, globalism and South Africa's political reconstruction. Cambridge: Cambridge University Press. https:// doi.org/10.1017/CB09780511560156

Kotze DJ (2004) The nature of democracy in South Africa. Politeia 23(3, 4): 10-21. KRIEGLER J (2016) Wie gaan opstaan? Beeld: Dinsdag 20 September 2016: 19.

LEVITSKY S AND WAY A (2015) Competitive Authoritarianism; The origins and dynamics of Hybrid Regimes in the post-cold war era. <Fsi.stanford.edu/ sites/default/files/events/media/Levitsky-Way-Stanford-pdf> (accessed 17 March 2016).

MCIBRAHIM INDEX OFAFRICAN GOVERNANCE IN WORLDJUSTICEPROJECT.ORG(accessed 10 March 2016).

MeRKeL W (2004) Embedded and defective democracies. Democratization 11(5): 33-58. https://doi.org/10.1080/13510340412331304598

NLEYE N (2011) Linking service delivery in South Africa: an exploration of evidence in Khayelitsha, Africanus, 50 (11): 3-13.

PLATtNer MF (2016) Is democracy in decline? Democracy \& Society 13(1): 1-7.

Rautenbach IM and Malmerbe efJ (1998) Constitutional Law. Durban: Butterworths.

SPARKS A (2016) Trump trompetter. Beeld, 8 Junie 2016: 21.

STEYN L (2016) Service delivery protest set for a new high during this election year, Mail and Guardian, 18 May 2016.

Sunday Times: 27 MAY 2016.

The Citizen: 8 APRIL 2016.

The Economist (2014) What's gone wrong with democracy 17 March: 43-48.

WAde ECS ANd BRAdLEy AW (1993) Constitutional and administrative law. Hong Kong: Longman.

World JUStiCE PRoject (WJP). Worldjusticeproject.org. (accessed 5 March 2016).

\section{Internet sources:}

www.fin.24.com/opinion/mcebisi-jonas-opens-up-on-state-

capture-20160422

(accessed 5 March 2016)

www.trandingeconomics.com.saudi/gdp

(accessed 5 March 2016)

www. theglobaleconomy.com.saudi/stab

(accessed 5 March 2016) 
www.fin.24.com/opinion/mcebisi-jonas-opens-up-on-statecapture-20160422

(accessed 5 May 2016)

www.fin.24.com/opinion/mcebisi-jonas-opens-up-on-state-

capture-20160422

(accessed 30 April 2016)

www.enca.com

(accessed 5 March 2016)

www.ssinesstech.co.za.news/government/100848/massive-drop-in-ancmembership (accessed 5 April 2016) 